\title{
PELATIHAN PEMBELAJARAN JARAK JAUH DI ERA PANDEMI COVID-19
}

Shulby Yozar Ariadhy ${ }^{1}$, Sabar Nurohman ${ }^{2}$, Darol Arkum ${ }^{3}$, Widya Handini ${ }^{4}$, Ferdiana ${ }^{5}$

${ }^{1345}$ Sekolah Tinggi Ilmu Sosial dan Ilmu Politik Pahlawan 12 Sungailiat

2Universitas Negeri Yogyakarta

Email: yozar@stisipolp12.ac.id

\section{RINGKASAN}

Merebaknya pandemi COVID-19 secara global telah mendorong banyak sektor kehidupan masyarakat yang mengalami perubahan termasuk di dunia pendidikan. Di Indonesia, sekolah dan perguruan tinggi telah meniadakan pertemuan atau tatap muka secara langsung. Sebagai alternatif, pemerintah Indonesia mendorong agar semua kegiatan belajar dilaksanakan secara jarak jauh. Pada sisi lain, pelaksanaan pembelajaran jarak jauh mengalami kendala seperti kurangnya ketrampilan guru atau tenaga pengajar dalam mengelola model pembelajaran tersebut, termasuk dalam menggunakan berbagai instrumen pembelajaran daring (online). Metode yang digunakan dalam pelatihan ini adalah penyuluhan, diskusi dan pelatihan. Peserta pelatihan diberikan pemahaman konseptual tentang pembelajaran jarak jauh sekaligus mempraktekkan penggunaan instrumen atau aplikasi pembelajaran daring seperti zoom, youtube, edmodo dan google form. Pelatihan ini telah berhasil mencapai tujuannya yaitu meningkatkan kapasitas peserta pelatihan dalam mengelola pembelajaran jarak jauh. Peserta diharapkan mempunyai kemampuan teknis dalam mengoperasikan berbagai aplikasi pembelajaran daring. Selain itu, peserta juga memahami bagaimana penerapan alat-alat pembelajaran jarak jauh tersebut secara tepat dalam rangka mencapai tujuan pembelajaran secara optimal. Kata kunci: Covid-19; Pembelajaran Jarak Jauh; Instrumen Pembelajaran Daring

\section{A. Latar Belakang}

Pandemi global Covid-19 telah mendorong terjadinya perubahan pada berbagai sektor kehidupan termasuk dalam pelaksanaan kegiatan belajar mengajar. Proses belajar konvensional dalam bentuk tatap muka menjadi tidak mungkin untuk dilakukan karena kekhawatiran terjadinya penularan virus tersebut. Meskipun tidak digolongkan sebagai kelompok rentan terhadap dampak kesehatan dari penyakit covid-19, anak-anak atau orang muda juga memiliki risiko untuk tertular penyakit ini (Siagian; 2020). 
Selanjutnya, selain berpotensi untuk terkena dampak kesehatan dari Covid-19, anak-anak atau orang pada usia sekolah akan ikut menanggung dampak sosial dan ekonomi dari pandemi global ini. Misalnya di sektor pendidikan, penutupan sekolah di Indonesia sejak bulan Maret 2020 dan dimulainya pembelajaran daring telah menimbulkan sejumlah permasalahan seperti kesenjangan akses terhadap pendidikan yang berkualitas, kesulitan orang tua dalam mendampingi proses belajar daring dan ketidakmerataan literasi digital siswa (Unicef;2020).

Pada sisi lain, Rigianti (2020) menyebutkan bahwa para guru juga mengalami sejumlah kendala dalam melaksanakan pembelajaran jarak jauh. Pertama, kesiapan menggunakan aplikasi pembelajaran. Pada tahap awal terjadinya penyebaran Covid-19, para guru dinilai tidak siap dalam menentukan instrumen pembelajaran secara cepat dan tepat sebagai pengganti dari pertemuan tatap muka. Kedua, akses terhadap jaringan internet dan gawai. Tingginya kebutuhan kuota internet dalam pembelajaran jarak jauh menjadi hambatan lain bagi para guru maupun siswa. Selain itu, tidak semua wilayah memiliki kualitas jaringan internet yang baik. Ketiga, kesulitan dalam pengelolaan pembelajaran. Guru harus mampu menemukan metode pembelajaran yang tepat agar kompetensi dasar yang diinginkan dari sebuah mata pelajaran dapat dicapai melalui pembelajaran jarak jauh. Keempat, kesulitan dalam menetapkan sistem penilaian yang obyektif.

Dari sisi dukungan regulasi terhadap pelaksanaan pembelajaran jarak jauh, pada awal merebaknya pandemi Covid-19, Menteri Pendidikan dan Kebudayaan Republik Indonesia mengeluarkan Surat Edaran Nomor: 4 Tahun 2020 tanggal 24 Maret 2020 yang mengatur sejumlah kebijakan seperti peniadaan ujian nasional dan fokus pendidikan pada kecakapan hidup antara lain mengenai pandemi Covid-19. Selanjutnya, pemerintah juga menerbitkan Peraturan Menteri Pendidikan dan Kebudayaan RI Nomor 19 Tahun 2020 yang antara lain mengatur tentang penggunaan dana Bantuan Operasional Sekolah (BOS) untuk pembelian pulsa, paket data dan/atau layanan pendidikan daring berbayar bagi pendidik dan/atau peserta didik. 
Berdasarkan daftar peraturan tersebut, dapat dilihat bahwa permasalahan kapaistas guru dalam melaksanakan pembelajaran jarak jauh belum mendapatkan perhatian yang memadai terutama pada masa awal pandemi global masuk ke Indonesia. Hal tersebut sejalan dengan hasil penelitian dari Dewi (2020) yang menyatakan bahwa masih terdapat permasalahan dalam kecakapan guru dalam menggunakan perangkat pembelajaran jarak jauh yang berbasis internet sehingga diperlukan pelatihan dan pendampingan yang dapat meningkatkan kapasitas guru dalam menggunakan instrumen pembelajaran dimaksud.

\section{B. Metode Pelaksanaan}

Kegiatan ini dilaksanakan di Kabupaten Bangka pada tanggal Mei 2020 dengan bentuk pelatihan daring yang terdiri dari tahapan sebagai berikut :

1. Tahapan persiapan

Pada tahap persiapan dilaksanakan identifikasi permasalahan yang terkait dengan implementasi pembelajaran jarak jauh melalui kajian terhadap data sekunder maupun observasi. Permasalahan yang teridentifikasi antara lain lemahnya kapasitas guru di Kabupaten Bangka dalam menggunakan instrumen pembelajaran jarak jauh.

Selanjutnya, dilakukan koordinasi dengan Dinas Pendidikan, Pemuda dan Olahraga Kabupaten Bangka sehingga dapat ditentukan sasaran kegiatan pelatihan pembelajaran dimaksud yaitu guru tingkat Sekolah Dasar dan Sekolah Menengah Pertama Se-Kabupaten Bangka.

\section{Tahap Pelaksanaan}

Pelatihan pembelajaran jarak jauh dilaksanakan secara daring melalui instrumen video conference "zoom". Materi pelatihan antara lain mengenai kebijakan pembelajaran jarak jauh di Kabupaten Bangka, pembelajaran interaktif dengan menggunakan "zoom", membuat dan mengelola e-learning menggunakan edmodo/google classroom, membuat quiz online. Adapun metode pelatihan terdiri dari penyampain teori dan praktek. 


\section{Tahap Evaluasi}

Evaluasi kegiatan dilaksanakan secara langsung pada saat sesi akhir pelatihan dan setelah pelatihan selesai dengan tetap menjalin komunikasi dengn peserta pelatihan melalui berbagai macam instrumen seperti media sosial.

\section{Hasil dan Pembahasan}

Kegiatan dilaksanakan dalam 3 (tiga) hari yaitu pada tanggal 4, 5 dan 7 Mei 2020. Pelatihan sepenuhnya dilaksanakan secara daring melalui aplikasi zoom. Dalam rangka persiapan pelatihan, peserta diminta untuk menginstal aplikasi zoom dengan mengikuti panduan tertulis yang dibagikan oleh panitia satu hari sebelum kegiatan pelatihan berlangsung.

Hari pertama pelatihan dibagi menjadi 2 (dua) sesi. Pada sesi pertama peserta diberikan penjelasan tentang kebijakan pembelajaran jarak jauh di Kabupaten Bangka oleh PIt. Kepala Dinas Pendidikan, Pemuda dan Olahraga. Sesi ini menitikberatkan pada dukungan Pemerintah Kabupaten Bangka terhadap operasionalisasi pembelajaran jarak jauh seperti penggunaan dana Bantuan Operasional Sekolah (BOS) untuk pembelian pembelian paket data bagi internet serta rencana pembekalan ketrampilan penggunaan instrumen pembelajaran jarak jauh bagi guru SD dan SMP di Kabupaten Bangka. Selain itu, sesi sosialisasi oleh PIt Kepala Dinas Pendidikan, Pemuda dan Olahraga Kabupaten Bangka juga menjadi sarana interaksi antara para guru dengan pengambil kebijakan sehingga terjadi komunikasi yang membahas faktor pendukung maupun penghambat bagi guru SD dan SMP di Kabupaten Bangka dalam melaksanakan pembelajaran jarak jauh.

Selanjutnya pada sesi kedua, topik pembahasan adalah pembelajaran interaktif dengan menggunakan zoom. Peserta pelatihan diajarkan tentang bagaimana menggunakan fitur-fitur yang ada di zoom seperti fitur chat (obrolan) dan screen sharing (berbagi layar). Fitur chat (obrolan) dapat digunakan untuk menyampaikan informasi secara tertulis serta membagikan file dengan jenis tertentu seperti dokumen pdf dan power point kepada para peserta konferensi video. 
Muatan materi lain yang terkait dengan zoom adalah bagaimana menjadi host (penyelenggara) dalam konferensi video zoom. Tugas seorang host adalah membuat tautan yang dapat digunakan oleh peserta untuk bergabung dengan konferensi, menetapkan peraturan dalam konferensi serta mengendalikan berjalannya zoom secara lancar. Meskipun bukan menjadi satu-satunya aplikasi yang dapat digunakan dalam proses pembelajaran jarak jauh, zoom dianggap sangat membantu dalam menciptakan proses belajar yang bersifat interaktif terutama untuk materi pelajaran yang membutuhkan video dan audio dalam proses komunikasi pembelajaran.

Narasumber pelatihan juga mengajak peserta untuk memahami tentang konsep dan praktik pembelajaran jarak jauh. Secara konseptual pembelajaran jarak jauh juga diharapkan tidak meninggalkan elemen pokok dari sebuah proses pembelajaran yang bersifat aktif yaitu seperti mengalami (experience), interkasi dan refleksi. Selanjutnya, pembelajaran jarak jauh juga dapat menggunakan dua strategi yaitu Synchronous elearning dan Asynchronous learning. Synchronous e-learning adalah sebuah model pembelajaran jarak jauh yang bersifat interaktif dengan menggunakan instrumen seperti video dan percakapan online sedangkan asynchronous learning merupakan proses pembelajaran jarak jauh yang bersifat non-interaktif serta menjadikan instrumen seperti internet sebagai pendukung saja misalnya sebagai alat utk menyampaikan tugas kepada siswa.

Pada sisi lain, pembelajaran jarak jauh secara daring melalui zoom membutuhkan kuota internet yang tidak sedikit sehingga para guru tidak disarankan untuk menggunakan aplikasi tersebut secara terus menerus. Instrumen pembelajaran harus bervariasi antara metode daring dan non-daring dengan memperhatikan muatan materi yang ingin disampaikan. Hal ini juga bertujuan untuk menghilangkan kebosanan di kalangan siswa.

Materi pelatihan hari kedua pada tanggal 5 Mei 2020 adalah membuat dan mengelola e-learning menggunakan edmodo/google classroom. Edmodo/google clasroom adalah instrumen pembelajaran jarak jauh yang dapat digunakan sebagai virtual classroom (ruang kelas virtual) sebagai sarana interaksi pembelajaran. Secara tampilan, edmodo 


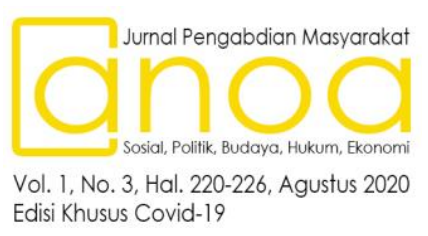

memiliki kemiripan dengan media sosial. Instrumen ini tidak menyediakan menu konferensi video namun memungkinkan guru dan murid untuk berinteraksi secara tertulis. Guru juga dapat mengunggah materi (tertulis, video atau audio) yang dapat dipelajari oleh siswa. Salah satu kelebihan dari bentuk kelas virtual ini dibandingkan dengan konferensi video adalah fleksibilitas dari segi waktu pelaksanaan dimana peserta tidak diharuskan untuk secara terus menerus hadir dalam proses interaksi pembelajaran.

Pada sesi tentang edmodo, peserta pelatihan diajarkan untuk membuat akun edmodo dan bagaimana langkah-langkah membuat kelas secara virtual. Akun edmodo memberikan pilihan untuk pengguna dalam menentukan perannya pada kelas virtual baik sebagai murid, guru atau orang tua. Selanjutnya, pembuatan kelas dapat dimulai dari dengan menentukan tingkatan kelas dan mata pelajaran yang akan diajarkan. Untuk keamanan proses belajar, masing-masing murid akan diberikan kode kelas untuk mengakses kelas yang sudah dibuat oleh guru. Adapun proses mengunggah materi atau interaksi di edmodo mirip dengan media sosial seperti facebook dimana guru dapat menulis sesuatu atau mengirim gambar serta video yang dapat dipelajari dan dikomentari oleh siswa. Kelas edmodo dapat memanfaatkan berkas (file) yang tersedia di perangkat komputer pribadi pengajar maupun yang bersumber dari dunia maya seperti pada platform youtube.

Kelas materi edmodo pada pelatihan ini juga memberikan kesempatan kepada peserta untuk mempraktikkan secara langsung proses penggunaan edmodo secara keseluruhan, mulai dari pembuatan akun dan kelas sampai dengan teknik mengunggah berkas (file) di sebuah kelas edmodo. Pada sesi praktik ini peserta dikelompokkan secara berpasangan dimana ada yang berperan sebagai guru dan ada pula yang manjadi murid di kelas edmodo. Tujuan pengelompokkan ini adalah agar peserta dapat merasakan secara langsung proses interaksi di kelas virtual.

Selanjutnya, materi membuat kuis dan tugas di kelas virtual edmodo disampaikan pada sesi akhir pelatihan. Materi ini antara lain mencakup tentang bagaimana membuat instruksi untuk sebuah tugas, mengunggah lampiran tugas dan menentukan batas waktu tugas. Adapun menu kuis edmodo menyediakan pilihan bentuk soal yang ingin 
